\title{
Para- and Proto-Sports Diplomacy of Contested Territories: conIFA as a Platform for Football Diplomacy
}

\author{
Ramesh Ganohariti \\ School of Law and Government, Dublin City University, Dublin, Ireland \\ ramganohariti@gmail.com \\ Ernst Dijxhoorn \\ Institute of Security and Global Affairs, Leiden University, Leiden, \\ The Netherlands \\ e.e.a.dijxhoorn@fgga.leidenuniv.nl
}

Received: 26 November 2019; revised: 21 April 2020; accepted: 23 May 2020

\section{Summary}

International relations and sport have become increasingly intertwined, with sport and sports events being used for various diplomatic and political goals. Yet, membership of FIFA and the IOC is largely organised along lines of sovereign statehood. Like other fora of diplomacy, this excludes contested territories that wish to engage in diplomacy for various political, economic, and cultural reasons. Yet, these entities can engage in international sports (diplomacy) through membership of the Confederation of Independent Football Associations (CONIFA). This paper finds that while the participating entities often make a political statement, there is little evidence that participation in CONIFA has positively impacted their foreign policy goals. Furthermore, beyond CONIFA, contested territories have been unable to advance their sporting sovereignty or engage in diplomatic relations with recognised states. However, CONIFA aids in nation branding through hosting rights and media attention, and contributes to strengthening the 'national' identity of the participants. 


\section{Keywords}

contested territories - diplomacy - paradiplomacy - protodiplomacy - sports diplomacy - football - Confederation of Independent Football Associations (CONIFA)

\section{Introduction $^{1}$}

In the summer of 2018, sixteen national teams participated in the Confederation of Independent Football Associations (CONIFA) World Football Cup that took place in London. Karpatalja took home the World Cup after beating Northern Cyprus 3-2 in the final. The previous World Cup winner, Abkhazia, was defeated early on in the tournament and ended in ninth place. The World Cup also brought teams representing Tibet, Cascadia, Matabeleland and Tamil Eelam to London. The strikers of Székely Land and Western Armenia may not be household names, the stadiums where the conifa World Football Cup took place were small and there was no prize money to be won. Yet the players were proud to compete and their compatriots happy to cheer them on. The participants in CONIFA's international tournaments represent a wide variety of autonomous regions, de facto states, and diaspora communities. The teams represent territories that are linguistically, culturally or historically distinct from the sovereign state they are part of, and they mostly do not feel represented by the government of the state they de jure belong to.

The participants in CONIFA may compete for divergent reasons and enjoy varying levels of sovereignty and self-determination but what they have in common is their limited external recognition and lack of sports sovereignty - in this case, membership in the Fédération Internationale de Football Association (FIFA). Despite lacking recognition as sovereign states, these entities (represented at CONIFA by their Football Association) seek to engage in international relations to further their political, economic and cultural goals. Yet even though non-state actors play an increasingly important role in international relations, the means to engage in para- or protodiplomatic relations are limited for these entities. By extension, the people living in them are un- or underrepresented on the international stage.

Participating in international sporting events provides a platform, albeit limited, for these entities. Through sports diplomacy, these conIFA members seek to create a positive image in the international arena, establish relations with

1 The authors thank the two anonymous reviewers of this article and Simon J. Rofe for their valuable insight and feedback. 
external actors and, thereby, try to further their foreign policy goals. However, the question is how far participating in the Conifa Football World Cup can contribute to the political, economic and cultural goals of its members.

This article first briefly discusses para-, proto-, and sports diplomacy. It then analyses how contested territories have used football diplomacy and the Confederation of Independent Football Associations as a platform to challenge their status quo. The predecessors to CONIFA are described, as are the stated goals of the organisation. The motivations of its participants and the way hosting rights could contribute to achieving the para- and protodiplomatic objectives of CONIFA members are considered. How participation in the CONIFA Football World Cup can aid in nation branding via positive media attention and aid in building international networks is assessed. Although it is not considered a para- or protodiplomatic goal of the members of CONIFA, the way sport can be used as a tool to strengthen (national, regional or other group) identity is also assessed. Finally, this article looks at the opposition to CONIFA from sovereign states and the limitations of para- and proto-sports diplomacy.

Paradiplomacy and Protodiplomacy

States are by no means the only actors that maintain transnational relations anymore. Not only do international governmental organisations and regional organisations play an increasingly important role in tackling global issues and engaging in cross-border relations and negotiations, so do multinational corporations, trade unions and international non-governmental organisations. ${ }^{2}$ However, traditional diplomacy, 'the practice of intermediary service on behalf of a sovereign state in relation to other sovereign states under international law', remains exclusively within the domain of sovereign states. ${ }^{3}$ While many of the traditional venues where the representatives of sovereign states meet remain closed to the representatives of non- or substate entities, their involvement in international relations is increasing around the world.

Part of this trend is the phenomenon whereby non-state and substate actors engage in a form of diplomacy usually referred to as paradiplomacy: a compound word for parallel and diplomacy. James McHugh defines paradiplomacy as any 'formal activity in which a sub-state actor engages in formal representation with states, international organizations or other parties that

2 Keating 1999, 6.

3 Cornago 2018, 1; McHugh 2015, 243. 
are conventionally recognized under international law'. ${ }^{4}$ However, like modern diplomacy, the involvement of substate actors in international relations can be achieved in a wide variety of ways. Foreign policy goals of non-state entities can be furthered through the establishment of both formal and informal contacts with representatives of foreign entities and can take the form of bilateral and multilateral relations by engaging with foreign public and private entities. ${ }^{5}$

The increased involvement of non-state actors in diplomacy can be explained through globalization, as transnational trade and flow of capital have made economies truly international and increased the need for multinational corporations, trade unions and regions to represent their interests. Increasing decentralization in some parts of the world and advances in communications technology have made cross-border social, economic and cultural exchanges much easier and have contributed to non- and substate entities securing a larger role for themselves in international relations. ${ }^{6}$ Sub-state entities may engage in paradiplomacy for political, economic and cultural purposes or, for instance, to promote environmental issues. ${ }^{7}$ Compared to interstate diplomacy, paradiplomacy is usually 'more functionally specific and targeted, often opportunistic and experimental. ${ }^{8}$ While central governments have often shown reluctance to accept the fact that the scope of international relations has broadened, paradiplomatic efforts are increasingly incorporated in the diplomatic strategies of states. ${ }^{9}$ In some cases, the right to engage in paradiplomacy may be constitutionally guaranteed by the state. Belgium, for instance, has a federal system that assigns far-reaching foreign policy powers to its subnational entities and the constitution of Iraq grants the Kurdistan region the power to implement foreign relations. ${ }^{10}$ However, in many states, any form of paradiplomacy is regarded with suspicion, especially as the foreign policy objectives of substate entities are not always in line with the diplomatic objectives of the sovereign state.

Noé Cornago argues that, besides serving its immediate goals, paradiplomacy is always a form of political agency and by engaging in relations with foreign actors, substate entities propagate a collective identity abroad. ${ }^{11}$ Paradiplomacy can also indicate a substate entity's desire for greater political

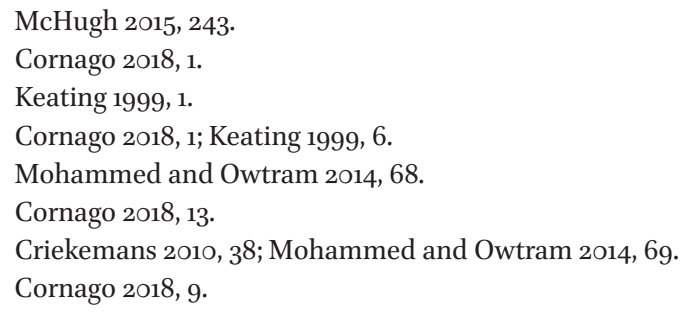


autonomy, or even secession from the sovereign state. When the purpose of engaging in international relations can be found in seeking international support for these statehood ambitions, paradiplomacy becomes protodiplomacy. Protodiplomacy can be defined as the 'efforts to promote claims of political independence or autonomy by a people or political subunit.'12 Protodiplomacy not only seeks legitimacy for the non-state entity but it is also used to promote an entity's interests and publicize the identity and culture of its people to seek international support. ${ }^{13}$ While protodiplomacy may be employed by regions or substate entities that have some form of formal status within the state, it can also be practised by national, linguistic or cultural groups that have no formal status within the existing state. 'Protodiplomacy ultimately seeks international legitimacy for the represented unit or people' mainly through activities related to cultural and national promotion and recognition. ${ }^{14}$

Like traditional diplomacy, protodiplomacy can be employed in parallel with the use or threat of armed force but it often demonstrates a will to secede while simultaneously avoiding high risk methods of seeking independence. ${ }^{15}$ Paul Kingston and Ian Spears argue that the diplomatic efforts of 'de facto' or 'quasi-states' such as Transnistria, Abkhazia, South Ossetia, Nagorno-Karabakh, Puntland and Somaliland can also be called protodiplomacy. ${ }^{16}$ However, protodiplomacy has its limitations and Cornago argues that success in acquiring an international diplomatic profile and securing significant international support for secession more often happens through the involvement of a powerful state than through the independent protodiplomacy of a secessionist entity, and that 'protodiplomacy rarely produces the results expected by its proponents'. ${ }^{17}$ Despite the limitations of para- and protodiplomacy, both substate and secessionist entities engage in international relations to further their political, economic and cultural objectives. They do so in various ways and para- and protodiplomacy can, for instance, take place in the form of public and economic diplomacy. The focus of this article is sports diplomacy; more specifically, how CONIFA members seek to use international sport as a platform for attracting attention and increasing their international standing.

\footnotetext{
12 McHugh 2015, 243.

13 Ducachek, Latouche and Stevenson 1988, 22-24; McHugh 2015, 244.

14 Der Derian 1997, 20.

15 Cornago 2018, 10.

16 Kingston and Spears 2004, 17-19.

17 Cornago 2018, 13.
} 
The interplay of sport and politics is nothing new; from the ancient Olympic Games onward, sport has played an important part in diplomatic engagements between polities. ${ }^{18}$ Through ping-pong diplomacy, cricket diplomacy or Olympic boycotts, states have long used sport to gain international attention and send political messages. The basic goal of diplomacy is to 'represent, promote and advance a nation's core values and interests' through peaceful means. ${ }^{19}$ This has been done through various types of diplomacy such as summit diplomacy, economic diplomacy, shuttle diplomacy and public diplomacy. One specific avenue that developed from public diplomacy is sports diplomacy, where political actors use sport and sporting events to achieve diplomatic and political goals. ${ }^{20}$

Sports diplomacy is a field that aims for long-term and stable cooperation amongst states..$^{21}$ Stuart Murray defines sports diplomacy as a practice that uses: 'Sports, people and sporting events to engage, inform, and create a favourable image amongst foreign publics and organisations to shape their perception in a way that is more conducive to achieving a government's foreign policy goals. ${ }^{22}$ Murray highlights that sports diplomacy has become an attractive tool for governments for various reasons: in the post-Cold War period, new forms of diplomacy were needed; sporting institutions were increasing their global reach and power, and sport garners a lot of public attention catalysed by mass media, represents ideals of peace by transcending differences and can be used as a tool for normalizing diplomatic relations. Furthermore, according to Carlos Pulleiro Méndez, participation in international sport projects the state's political and economic achievements and can become a precursor for high-level diplomacy. ${ }^{23}$ Additionally, sport can also help foster group identity. ${ }^{24}$ Despite the positive dimensions associated with sports diplomacy, sport can also be used as a propaganda tool such as the 1936 Berlin Summer Olympics or the 2014 Sochi Winter Olympics. ${ }^{25}$

\footnotetext{
18 Gauthier 2019, 233.

19 Murray 2012, 578.

20 Black and Peacock 2013, 708; CONIFA Official-Media Team, interviewed by the first author via Skype, 11 November 2018.

21 Štulajter and Štulajter 2016, 385 .

22 Murray 2012, 581-582. See also Allison and Monnington 2002.

23 Pulleiro Méndez 2O2O, 5.

24 Field 2014; Rofe 2016, 221.

25 Gauthier 2019, 233-234.
} 


\section{Sports Diplomacy and Contested Territories}

International sport is principally governed by a transnational mechanism known as the 'Olympic Movement'. This movement comprises the International Olympic Committee (IOC), International Federations (IFs) that are responsible for specific sports and National Olympic Committees (NOCs) who represent 'their respective countries at the Olympic Games and at [other] multi-sports competitions patronised by the IOC'.26 Strictly speaking, athletes do not represent states at international sporting events but rather compete as members of an NOC or a National Federation. ${ }^{27}$ National Federations usually correspond to sovereign states but there are some exceptions; namely, for historical reasons and because IFs and the IOC in the past used criteria for recognising national sporting bodies that were not directly linked to sovereign statehood. ${ }^{28}$

The largest sports events in the world are organised by the IOc (the Olympic Games) and FIFA (the Football World Cup) Therefore, if a sports federation representing a (contested) territory gains admittance to the IOC and FIFA, it can be argued that it has achieved the highest form of recognition in the sporting world. For example, Palestine and Kosovo have been able to become members of the IOC and FIFA, despite lacking universal recognition as states. A territory being permitted to be represented by athletes at large sporting events can also be a signal that an entity is well on its way to recognition as a sovereign state; for instance, East-Timor's participation in the 2000 Olympics under the Olympic flag shortly before independence is a poignant example. Recognition of a National Federation by an IF 'demonstrates that the entity seeking statehood can exercise independence in an area of human activity'. ${ }^{29}$ Furthermore, participation in popular sporting events has been used to build

\footnotetext{
26 IOC 2019, Rule 1, 25 and 27.

27 Gauthier 2019, 237-241.

28 For various historical reasons, FIFA (211 national associations) and the IOC (206 NOCs) have accepted non-sovereign territories, but almost always with the blessing of the base state. Currently, American Samoa, Aruba, Bermuda, British Virgin Islands, Cayman Islands, Cook Islands, Guam, Hong Kong, Kosovo, Palestine, Puerto Rico, Taiwan (Chinese Taipei), and US Virgin Islands have Nocs despite lacking Un membership. Similarly, the following non-UN members compete independently in FIFA: American Samoa, Anguilla, Aruba, Bermuda, Cayman Islands, Cook Islands, Curaçao, Faroe Islands, Gibraltar, Guam, Hong Kong, Kosovo, Macao, Montserrat, New Caledonia, Palestine, Taiwan (Chinese Taipei), Turks and Caicos Islands, US Virgin Islands, England, Scotland, Northern Ireland, and Wales. In contrast, Federated States of Micronesia, Kiribati, Monaco, Nauru, Palau, and Tuvalu are not members of FIFA despite being full UN Member States.

29 Gauthier 2019, 255.
} 
a case for statehood and membership of fora beyond sport. Participation is a symbolically important political endorsement of the legitimacy of the participating entity and allows the contested territory to 'act like an established state on the international stage. ${ }^{30}$

Despite the aspiration of a wide range of (contested) territories to independently engage in international sports events, the way that international sport is governed means that entities that lack recognised sovereign statehood are usually excluded, as they are from other fora where diplomatic relations are conducted. Because of the importance of participating in sports events under their own flag, both symbolically and for creating external and internal legitimacy, the question of who has the authority to represent a certain region in international sport remains highly contested. Contested territories can use sport as a para- or protodiplomatic tool to further their political, economic and cultural goals and even to strengthen their claim to recognition and signal an arrival as legitimate states in the international system. Having an internationally recognised national sports association can 'legitimize the very existence of a state or a state-like polity'. ${ }^{11}$ Pulleiro Méndez argues that recognition as a sporting sovereign state is dependent on the sports power of the polity and international political support of the contested territory. Only if the contested state can garner an adequate level of international support, like Kosovo, will it be admitted to International Federations such as FIFA or the IOc. ${ }^{32}$

Despite their efforts, most non- or substate entities with established sporting associations have been unable to garner adequate international support and gain admittance to FIFA or the IOc. Each IF makes its own rules as to who is eligible for membership and who is not. However, they generally follow the idea that a member has to represent a 'country'. According to the Olympic Charter, 'the expression "country" means an independent State recognised by the international community',33 with the NOC representing this 'country'. However, this definition has been used only since 1996, prior to which 'the expression "country" [was taken to] mean any country, state, territory or part of a territory which the IOC in its absolute discretion considers as the area of a recognized NOC. ${ }^{34}$ Similarly, according to the FIFA Statutes, 'any association

$30 \quad$ Allison and Monnington 2002, 107; Black and Peacock 2013, 713-714; Gauthier 2019, 234; Rookwood 2019, 3-4.

31 Black and Peacock 2013, 713; Kobierecki and Strożek 2017, 701.

32 For further discussion on Taiwan's and Kosovo's positions in international sport, see Pulleiro Méndez 2020; Gauthier 2019.

33 IOC 2019, Article 30-1.

34 IOC 1995, Article 34-1. 
which is responsible for organising and supervising football in its country may become a member association.' ${ }^{35}$ In this case, the expression 'country' also refers to 'an independent state recognised by the international community'. Thus, by and large, the state has become the base unit of representation for National Federations and Noc. ${ }^{36}$ This definition clearly restricts federations representing non-states from becoming members of FIFA. According to Article 11-6 of the FIFA Statutes, the only exception for their admittance would be to gain authorisation from the country which they are de jure part of (i.e., base state). However, this would not be a politically viable option for most contested territories as they are in a situation in which statehood is contested vis-à-vis the base state. Being admitted to FIFA under Article 11-6 of the FIFA Statutes would show that the entity accepts the supreme authority of the base state or would imply a recognition of the statehood functions of the territory by the base state. However, when substate entities take steps to join IFs, it is usually seen as a threat to the territorial integrity of the base state. ${ }^{37}$

Because of the restrictions placed on the membership of IFs for sports organisations representing contested territories, people living in territories that are the subject of contested statehood often cannot participate in international sporting events. And if they can, they cannot do so under the flag of the contested territory. Players are either obliged to play for the base state (e.g., Iraqi Kurds for Iraq), or have to play under the flag of another state whose citizenship they possess (e.g., Russia for Abkhazians, Turkey for Northern Cypriots). ${ }^{38}$ Thus, due to the above-motioned restrictions and limited international support for their political and sports sovereignty, most members of sporting associations of contested territories have been restricted from joining and participating in international sporting events. As a result, many contested territories have been forced to seek other alternatives for engaging in international sport.

35 FIFA 2018, Article 11. Both the Olympic Charter and the FIFA Statutes seem to adhere to the constitutive theory of statehood in which statehood foremost depends on recognition by other states.

36 Pulleiro Méndez 2020, 4-5.

37 Pulleiro Méndez 2020, 3.

38 Some of the players and coaches on CONIFA teams have played for national football teams or clubs in recognized states such as Russia, Romania, Slovakia, Hungary and North Korea. 
The limited possibilities to participate in international sports events organised by IFs or the IOC — and by extension for engaging in sports diplomacy — have caused contested territories to seek alternative ways to engage in international sport. The Basque government, for instance, has funded an international cycling team (Euskaltel-Euskadi) and the Catalan Football Federation, although not a member of FIFA, organises friendly matches for its national football team, mainly against other national football teams that are members of FIFA. In the world of football, there have been numerous 'World Cups' in which non-FIFA members have been able to participate. These include the viva World Cup (2006-2012) by the New Federations Board; the Equality, Liberty, Fraternity Cup (2006); the Federation of International Football Independents (FIFI) Wild Cup (2006); Unrepresented Nations \& Peoples Organization (UNPO) Cup $(2005,2017)$ and the 2016 World Unity Cup. ${ }^{39}$ However, these events were either one-time events, or the bodies that organised them no longer exist. The only active football organisation that represents non-FIFA members is the Confederation of Independent Football Association, established in June 2013.

Not all of the 58 CONIFA members are contested territories since the membership criteria are much broader. Members that are not politically contested include Monaco, Tuvalu and Kiribati which are full UN members, and substate regions like Greenland or Quebec that have managed to negotiate their status within a larger state despite historic contestation. Contested territories can take the form of de facto states (e.g., Abkhazia, Northern Cyprus), occupied territories (e.g., Western Sahara, Western Papua, Chagos Islands, Tibet) or territories with a significant minority (e.g., Karpatalja, Székely Land). Thus, as can be seen, CONIFA has a broad spectrum of members, and this article specifically focuses on those CONIFA members that are politically contested territories.

CONIFA, unaffiliated with FIFA, defines itself as a 'global acting non-profit organization that supports representatives of international football teams from nations, de facto nations, regions, minority peoples and sports isolated territories. ${ }^{40}$ In practice, this means that any Football Association representing a territory, nation or people that is not a member FIFA is eligible for CONIFA membership. ${ }^{41}$ Perhaps one of the best ways the contrast between FIFA and CONIFA has been summarised is by Paul Watson, conifA's Commercial Director, who states that '[while] FIFA's system tells you your

39 Field 2014; Shobe and Gibson 2017, 956, 963-964; UNPO 2017.

40 CONIFA n.d.

41 CONIFA 2014. 
identity, CONIFA's asks you your identity', thereby providing communities the opportunity for self-determination in sport. ${ }^{42}$ CONIFA claims to be an apolitical organization, and the rule is to 'ban political or nationalist statements during match days and events'.43 But despite its apolitical mission of providing a platform for people with a common identity to play football, the whole purpose of CONIFA can be interpreted as political, given that it provides a platform for, and thus recognition of, contested territories. ${ }^{44}$ Joel Rookwood concludes that 'events that CONIFA organise[s] and the locations selected to host them could be considered to be heavily politicised, even if the expressed intent at an organisational level is to remain non-political. ${ }^{45}$ Russell Field, in his research on the 2010 viva World Cup, came to a similar conclusion, though he contends that the tournament added to the cultural rather than political legitimacy of the participating members. He argues that 'politics' is narrowly defined to mean the absence of politics on the playing field itself. ${ }^{46}$ This seems to be the case for CONIFA as well. Thus, participating in CONIFA in itself can be seen as a political statement. ${ }^{47}$

First, the political, economic and sociocultural demands of many of the contested territories represented at CONIFA are suppressed by their base state. Many emerged from conflict and have been prevented from engaging in the international political system. By playing in 'national' jerseys and displaying symbols of (aspiring) statehood (e.g., flags, anthems), these entities are making a statement. ${ }^{48}$ By demanding their right to participate in international sport, they seek to claim their place in the international system in general. Furthermore, being denied the simple joy of seeing eleven of their countrymen play football' adds further insult to injury. ${ }^{49}$ By participating in CONIFA, the only sports platform of its type currently in existence, players from contested territories can proudly represent their nation or community. ${ }^{50}$ For the players and fans of CONIFA members such as Abkhazia, Tibet, Tamil Eelam or

42 Paul Watson, as quoted in Ginnell 2018, para. 7.

43 Deeley 2019; 202; Ginnell 2018, para. 10.

44 Deeley 2019, 66; ConIfa Official-Media Team interview; Utomo 2019, 28-29.

45 Rookwood 2019, 8.

46 Field 2014, 390-391.

47 Utomo 2019, 25, also argues that CONIFA itself has become a paradiplomatic actor as it provides a platform for 'members to interact with like-minded counterparts' and allows the issue of self-determination to reach a wider audience.

$48 \quad$ Field 2014, 386.

49 Cook 2018, para. 23.

$50 \quad$ Orcun Kamali (Northern Cyprus), as cited in Deeley 2019, 93-94. 
Matabeleland 'tragedy is never far from the surface at CONIFA' ${ }^{51}$ and, through this platform, they can be given a voice to 'share their side of the story'.52

It has also been argued that international sport has become a 'proxy for hotter forms of conflict.'53 Most commonly cited examples include the 1980 and 1984 Olympic boycotts, sports sanctions against apartheid South Africa, the 1956 'Blood in the water' match between Hungary and the UssR, or the 'Miracle on Ice' ice hockey match between the USSR and the United States at the 1980 Olympics. ${ }^{54}$ By extension, through participating in events like CONIFA, contested territories protest against the base state by refusing to compete under the same flag. Yet as discussed in the previous sections, the objectives of entities to engage in para- or protodiplomacy are wide-ranging, and goals of members of CONIFA are not universal either. The reasons for membership in CONIFA can range from bringing awareness to their group's existence and playing as a unified team, to using football as a protodiplomatic/political platform to demand greater autonomy or display their aspirations for sovereign statehood. ${ }^{55}$ Thus, as Jonny Weeks puts it, 'the scale of ambition shown by CONIFA's members varies: some are happy to have international opponents at last, some hope FIFA will one day recognise them, others plan to take on the world'. ${ }^{56}$

Additionally, participating in sports events can help create or consolidate a (claimed) common identity, and bring forth the question of national identity and belonging. In some cases, multiple national identities do not necessarily conflict with each other; for instance, being English and British. But more often than not, national identities are mutually exclusive - few people consider themselves both Abkhaz and Georgian, or Tibetan and Chinese. CONIFA takes the different forms of group identification into account and calls all its participants 'members'. Thereby, CONIFA allows the teams to use the label they feel represents them best, rather than the label of the state that they de jure belong to. Thus, by participating in such events, CONIFA members can easily challenge the 'mainstream notions of national identity' ${ }^{57}$

The use of sport to achieve diplomatic goals is not free from criticism. One such critique is that international sports events encourage 'nationalism through flag-waving, national anthems, and exhortation to patriotism', and

\footnotetext{
$51 \quad$ Engel 2018, para. 6.

$5^{2}$ CONIFA Official-Global Team, interviewed by the first author via Skype, 29 August 2018.

53 Black and Peacock 2013, 711.

54 Padhi 2011, 57-59; Štulajter and Štulajter 2016, 384.

55 Conifa Official-North America Team, interviewed by the first author via Skype, 23 May 2018; Withnall 2018.

56 Weeks 2018, para. 26 .

57 Field 2014, 378.
} 
thus counter the ideas of peace and tolerance. ${ }^{58}$ However, for contested territories, this 'flag waving' seems to be one of their primary goals. By playing as a 'national' team, CONIFA members can show that the group they belong to is different from the sovereign state they are attributed to and, in turn, use this uniqueness as a reason for claiming sovereignty in sport, and possibly in the international system in general. Even back in 1945, George Orwell critiqued international sport for mimicking warfare and strengthening nationalism. ${ }^{59}$ Teams participating in CONIFA can use it as a platform for furthering their fight for self-determination. ${ }^{60}$ Finally, states have used sports events as a platform to signal their arrival as legitimate countries in the international system. ${ }^{61}$ The same appears to be true for contested territories.

States have increasingly used sport as a soft power tool for nation branding to create a positive image both domestically and abroad. ${ }^{62}$ Nation branding can be defined as 'a process by which a nation's images can be created or altered, monitored, evaluated and proactively managed to enhance the country's reputation among a target international audience.63 According to Michał Marcin Kobierecki and Piotr Strożek, small and medium states aim to become more visible, while larger states aim to be seen in a better light. ${ }^{64}$ This research also argued that there is a positive correlation between positive sports performance (counted by the number of Olympic medals, for instance) and a (positive) national image. ${ }^{65}$ Furthermore, CONIFA members not only want to become more visible but also to promote understanding and create a positive image of their region. Most contested territories, such as Abkhazia, Transnistria and South Ossetia, get limited media attention outside of their respective regions and the attention they do receive is often negative, depicting them as places filled with conflict and danger. Thus, by engaging in sporting events, contested territories

\footnotetext{
$5^{8} \quad$ Murray 2012, 587 .

59 Murray 2012, 587 ; Orwell 1945, para. 4.

6o Utomo 2019, 26.

61 Black and Peacock 2013, 713 .

62 Allison and Monnington 2002, 107.

63 Fan 2010, 101.

64 Kobierecki and Strożek 2017, 698.

65 Kobierecki and Strożek 2017, 698.
} 
wish to be seen globally and to 'get over all the conflict that many of them are associated with'.66

\subsection{CONIFA as a Nation Branding Tool via Hosting Rights}

Hosting sports events can also be seen as a soft power tool to showcase a state's grandeur and improve the national image internationally. ${ }^{67}$ For example, beginning with the 1995 Rugby World Cup, South Africa has used the hosting of sports events to present itself in a positive light and rid itself of the negative image resulting from the apartheid era; Japan has used football and the Olympic Games to alter its imperialist image; and Qatar hopes to use the 2022 FIFA World Cup to attract tourism, debunk negative stereotypes, and gain visibility as a regional and global actor. ${ }^{68}$ Therefore, one important point of analysis could be the choice of venue for the CONIFA tournament. CONIFA 2018 was held in London from 31 May to 9 June (hosted by Barawa) and the previous two World Football Cups were held in Abkhazia (2016) and the Sápmi region of Sweden (2014). The CONIFA European Cups of 2015 and 2017 were held in Hungary (hosted by Székely Land FA representing a Hungarian minority in Romania) and Northern Cyprus, respectively. The 2019 European Cup was held in Nagorno-Karabakh. ${ }^{69}$ Contested territories that choose to host CONIFA seem to provide similar arguments as those put forward by sovereign states hosting sports megaevents. Particularly, contested territories use the event as an 'exercise in external legitimacy building', ${ }^{70}$ to gain international attention and to show the world that they too can organise sports events. ${ }^{71}$

66 CONIFA Official-Global Team interview.

67 Grix and Brannagan 2016, 252.

68 Brannagan and Giulianotti 2018; Grix and Brannagan 2016, 264-266; Manzenreiter 2008; Padhi 2011.

69 In London, the tournament was hosted by the Barawa community hailing from Somalia; thus, officially, the event did not take place in London. The main reason for choosing London was because the event was sponsored by Paddy Power, a bookmaker with betting rights in Ireland and the UK. If Paddy Power was to sponsor the event and ensure betting on the matches was possible, the UK and Ireland were the only options. CONIFA was also able to gain more coverage through the Paddy Power network and, in turn, increase the international visibility of the participating teams. In other cases, the events were sponsored by the local governments of the contested territories hosting the event. Cook 2018; Engel 2018; Harris 2018; CONIFA Official-Global Team interview; CONIFA Official-Media Team interview.

70 CONIfA Official-Media Team interview.

71 CONIFA Official-Global Team/Abkhazian Official, interviewed by the first author via phone, 5 October 2018. 


\subsection{CONIFA as a Nation Branding Tool via Media}

The growth of the sport-media complex has made sport easily accessible to people across the world. ${ }^{72}$ Moreover, football diplomacy 'constitutes a field that can be exploited and mobilized for specific policy goals in international relations as well as in domestic affairs'. ${ }^{73}$ Sporting victories are of vital importance for nation branding and propaganda, particularly as a result of media coverage for the winning team. ${ }^{74}$ It is an exercise of selling culture and identity to the world. Through this exposure, participants also clearly envisage bringing attention to their political causes. ${ }^{75}$

By participating in CONIFA, contested territories seem to have the same goals as state actors: getting positive media attention and raising awareness of their existence. ${ }^{76}$ While unlike the Olympics or FIFA, CONIFA has yet to be broadcast on 'national' television; the development of technology has allowed CONIFA to bypass national broadcasters. In 2018, fans were able to stream 30 of the 49 matches (free of charge) via Mycujoo.tv, a football streaming platform. According to a Mycujoo representative, there were 91,513 users and 454,372 views across the course of the event. ${ }^{77}$ The most-watched (live) match was the Abkhazia versus Tibet opening match with 39,931 views and a further 3,000 on-demand views in the days that followed. ${ }^{78}$ Geographically, most viewers were from the UK, Romania and India (see Table 1 below). ${ }^{79}$ In total, there were individuals from 108 countries and territories who viewed the matches. Ironically, the data on views is available only according to the International Telecommunication Union's list of countries/regions. By analysing the data, seven of the top 20 countries were either large diaspora host nations or patron states of one of the participating members, and nine of the top 20 countries were those to which a CONIFA member de jure belongs. ${ }^{80}$ Based on these results, it could be argued that the greatest number of viewers were in regions

$72 \quad$ Black and Peacock 2013, 717; Field 2014, 385 .

73 Manzenreiter 2008, 415 .

74 Field 2014, 387; Kobierecki and Strożek 2017, 702-703.

75 Shobe and Gibson 2017, 955-956.

76 CONIFA Official-Global Team/Abkhazian Official interview; conIfa Official-Media Team interview.

77 Mycujoo Representative, personal communication, 26 September 2018. Data is accurate as of 26 September 2018.

78 Matches and highlights can be accessed via https://mycujoo.tv/video/conifa.

79 Officials from Mycujoo warned that when interpreting these numbers, it is important to keep in mind that many viewers may have been using a virtual private network service, especially in countries with restrictions and a poorer or less stable connection. Similarly, the figures for Brazil are high due to a marketing campaign run at the time of the event.

80 Turkey is both a patron state of Northern Cyprus and the base state of Western Armenia. 
TABLE 1 Top 20 regions by number of views of football matches

\begin{tabular}{llllllll}
\hline Country & Views & Country & Views & Country & Views & Country & Views \\
\hline UK & 85,971 & Russia & 21,166 & Brazil & 12,558 & Switzerland & 6,308 \\
Romania & 67,902 & Hungary & 19,453 & Germany & 11,695 & Canada & 5,301 \\
India & 24,325 & Italy & 19,453 & Ukraine & 10,502 & Argentina & 4,318 \\
France & 21,772 & Armenia & 18,127 & Japan & 10,478 & Turkey & 4,027 \\
United & 21,681 & Georgia & 16,881 & Algeria & 8,140 & Spain & 3,946 \\
States & & & & & & & \\
\end{tabular}

SOURCE: MYCUJOO REPRESENTATIVE, PERSONAL COMMUNICATION, 26 SEPTEMBER 2018.

that the CONIFA members had a strong connection to. Outside those regions, there were fewer people watching the matches and, thus, the success of garnering public attention through online streaming in third countries seems to be limited. On the other hand, it can be argued that, at a minimum, the viewers from the regions listed in Table 1 would not only watch their 'home' team compete but also gain awareness of the other teams competing in CONIFA and, by extension, awareness of other contested territories. ${ }^{81}$

The 2018 event was also attended by over 400 journalists and was reported by prominent newspapers and news agencies, including The Guardian, Al Jazeera, France 24, Times of India, South China Morning Post, B BC, and RT. Thus, using sport as a tool, CONIFA members hope to receive positive coverage, as well as make more people across the world aware of their existence. ${ }^{82}$

Compared to other means of conducting international relations, participating in sports events is seen as a low-risk, low-cost, high-visibility activity. ${ }^{83}$ This is partially true for contested territories, as it may be a low-cost and high-visibility activity but not always low risk. ${ }^{84}$ As discussed in Section 9 'Opposition to CONIFA', due to the participation of a team representing the contested territory, the team members and their families could face negative consequences from the authorities of base states. Despite the media attention

\footnotetext{
$81 \quad$ The CONIFA Twitter account had 6 million Twitter impressions during the 2018 World Cup. CONIFA Official-Media Team interview; Rookwood 2019, 11.

82 CONIFA Official-Global Team interview; CONIFA Official-Media Team interview; Rookwood 2019, 11-12.

83 Black and Peacock 2013, 711; Mark Keech and Barry Houlihan, as cited in Murray 2012, 583.

84 There is a further caveat in relation to the level of 'low-cost-ness' of participating in international sports. Some teams (e.g., Tibet, Matabeleland) have had to work hard to gather the funds necessary to travel to and participate in CONIFA.
} 
and the availability of a platform for engaging with various actors, it is important to note that CONIFA members do not engage with the most important actors in international relations (i.e., sovereign states).

Sport can also be used as a way to conduct cultural diplomacy, such as the famous ping-pong diplomacy between the United States and China or cricket diplomacy between India and Pakistan. ${ }^{85}$ Sport results in cultural exchange and the creation of new and stronger networks between the participants and their governments. One example is when the co-hosting of the 2002 FIFA World Cup by Japan and Korea 'caused the formation of a fragile, yet gradually viable, alliance between the two states and their people' ${ }^{86}$

Sports events such as CONIFA seek to bring people together and promote cultural exchange between the teams, the viewers, and the diaspora communities based in the host city. ${ }^{87}$ Additionally, by citing the example of cooperation between the Kurdistan and Northern Cyprus Football Associations, a CONIFA Official on the Media Team argues that CONIFA provides a platform for peace and dialogue between groups that may have wide political differences. ${ }^{88}$ Furthermore, what unites many CONIFA participants is their common history of struggle (however, this may be defined), and through these platforms they can share these experiences and show each other the power of their resilience. This is best described by Robert O'Connor in one of his news pieces: 'On the final day, the Kabylians sat on the roof ... and watched the final in the rain with their new Abkhazian friends. The flags of both nations fluttered side by side in the wet breeze, a fraternity forged on the football field, immortalized by circumstances.' ${ }^{89}$

CONIFA as a Tool to Strengthen (National) Identity

Though beyond the scope of this research (as it is mainly an internal objective for participating in international sports events), sport is also a nation-building

\footnotetext{
85 Black and Peacock 2013, 713.

86 Manzenreiter 2008, 42 .

87 Field 2014.

88 CONIFA Official-Media Team interview.

89 O'Connor 2018b, para. 70.
} 
tool. Sport is a way to unite people under one flag, show the group's unique identity, ${ }^{90}$ and thereby consolidate and strengthen group identity. ${ }^{91}$ However, when statehood becomes contested, sport becomes less benign and becomes a powerful (political) tool for building a collective identity and displaying it internationally. Football, in particular, can be used to mobilise communities by making them gather around something tangible. ${ }^{92}$ Examples of territories that are not independent states but participate independently in international sports events include Aruba and Bermuda in FIFA, Puerto Rico at the Olympics and Abkhazia and Kurdistan at Conifa. In particular, 'for nations that lack representation in the political world, soccer clubs can become a venue through which national status is asserted. ${ }^{93}$ Especially when outlets for pride, identity and patriotism are limited, sport can be one of the last venues for people to peacefully support their homeland or identity. People can show their pride and patriotism, and represent the team that they best identify with, as shown by the following quotes:

That's where I'm from, that's where my family is from.... I always wanted to be an international footballer, and I thought to do that I'd have to represent Turkey because Northern Cyprus can't take part in a World Cup ... and yet to be in the final tomorrow - can't wait. ${ }^{94}$

When we hear our national anthem, and we can see our national flags flying in the ground, it makes us realise we have already achieved a lot.... The important thing is to say that we are here, we Tibetans can also play football, and to show that we have equality. ${ }^{95}$

9o A group's identity can take many forms. For some, like Abkhazia and Kurdistan, it is an ethnolinguistic identity. Other teams represent a linguistic identity of a people in a specific geographical region such as Karpataljans, a Hungarian-speaking minority who hail from Western Ukraine. By accepting members under a very flexible view of identity, CONIFA allows a plethora of people groups to partake in international sports. Paul Watson, as cited in O'Connor 2018a.

91 Allison and Monnington 2002, 126-128; Rofe 2016, 220-221. However, as argued by Bertoli $2017,837-839$, international sporting events can have negative consequences as national rivalries on the field can morph into political conflict between states (e.g., Football Wars between El Salvador and Honduras in the 196os, the Union of European Football Associations (UEFA) 2014 England-Russia riots and the UEFA 2014 Serbia-Albania drone conflict).

92 Shobe and Gibson 2017, 956.

93 Shobe and Gibson 2017, 595; Utomo 2019, 29.

94 Necati Gench (Northern Cyprus), as cited in Conifa 2018a. See Deeley 2019, 86-99, for discussion of Northern Cyprus's participation in CONIFA 2018.

95 Passang Dorjee (Tibet), as cited in Withnall 2018, para. 26. 
Secondly, sport can be used to show the uniqueness of the group, challenge the dominant (base state) identity ${ }^{96}$ and exhibit the independent character of the contested territory. ${ }^{97}$ Furthermore, using the case of Cascadia, Hunter Shobe and Geoff Gibson argue that football is a channel through which ideas about the region are communicated and experienced..$^{98}$ It is a similar case for Tibet, where 'football is the closest thing Tibetans have to a national sport'. 99 Wolfram Manzenreiter also notes that sports tournaments are a vehicle for the display of nationalism and the achievements of the state. ${ }^{100}$ Football is 'about empowerment. This is football that transcends, even subverts the politics of the established international competitions. Here, the geopolitical map is ripped up and redrawn'.101 That said, a CONIFA Official on the Media Team stressed that it is important to be aware of the motivations of different actors and, while the elites of contested territories may use the participation in CONIFA for political reasons, the players themselves may do it just for their love of football. ${ }^{102}$ Thus, it can be argued that sport can be regarded as a tool for strengthening national identity and, therefore, an important objective for participating in events like the CONIFA World Football Cup.

\section{$9 \quad$ Opposition to CONIFA}

While CONIFA aims to promote inclusivity and leave the politics out of the football tournament, the participants and the organisers have not been free from criticism and opposition due to the contested nature of many of its members. ${ }^{103}$ The biggest opposers have been the representatives of base states whose sovereignty is contested. To limit positive media attention for these regions, CONIFA and participating teams have had various restrictions and ultimatums placed on them. Some teams choose to participate despite great opposition and threats from the authorities of their base states. For example, the Algerian authorities see Kabylia's participation in CONIFA as a claim for

\footnotetext{
96 Shobe and Gibson 2017.

97 CONIFA Official-Global Team/Abkhazian Official interview; O'Connor 2018a.

98 Shobe and Gibson 2017, 962-968.

99 Tenzin Nyendak (Tibet), as cited in Withnall 2018, para. 21.

100 Manzenreiter 2008, 415.

101 O'Connor 2018b, para. 61. For further analysis of the use of sport by contested territories for building national identity see Field's 2014 work on the 2010 viva World Cup.

102 CONIfA Official-Media Team interview.

103 Per-Anders Blind, as cited in Weeks 2018; conifa Official-Global Team interview.
} 
independence and fear that the Kabylians would 'do something positive'.104 Similarly, in Ukraine, the Sports Minister accused the Karpataljans of 'sporting separatism'. Following the event, the Ukrainian Football Federation disqualified the players from playing in Ukraine for life, and the Ukrainian Security Service has taken steps to ban them from entering the country. ${ }^{105}$ Another controversial participant in 2018 was Tibet. According to Watson, CONIFA's Commercial Director, the Chinese government pressured potential sponsors to withdraw from sponsoring the event if Tibet were to participate. ${ }^{106}$ CONIFA did not succumb to this pressure but, as a result, ended up having only one main sponsor. There was also opposition from diaspora communities of the base states. The Greek Cypriot community in Enfield (one of the hosting boroughs in London) protested at their local council against the participation of Northern Cyprus. ${ }^{107}$ Similarly, there were several Georgian protesters present during the Abkhazia versus Tibet match. ${ }^{108}$

In several instances, the participation of CONIFA members in the CONIFA World Cup has been politicised. For instance, the Tibetan team's UK visas were held up for two months and several players from Kabylia were denied visas altogether. ${ }^{109}$ Similarly, in the 2015 CONIFA European Football Cup, the Abkhazian, South Ossetian and Northern Cyprus teams withdrew from the competition because the Hungarian authorities refused them visas. ${ }^{110}$ These examples demonstrate the difficulties faced by sportspeople representing contested territories. But it also shows that engaging in sports diplomacy to further their political, economic or cultural objectives is not any easier for contested territories than engaging in other forms of diplomacy.

While the motivations for CONIFA members to engage in sports diplomacy, and the possible benefits of doing so were described above, there are indeed several limitations to linking sport and para- and protodiplomacy. First, sports diplomacy by itself often is an insufficient tool to forge foreign relations. ${ }^{111}$

\footnotetext{
104 Aksel Bellabbaci, as cited in O'Connor 2018b, para. 26.

105 Channel24 2018; CONIFA 2018b; Williams and Polityuk 2018.

106 Engel 2018; Withnall 2018.

107 O'Connor 2018a; Weeks 2018.

108 CONIFA Official-Global Team/Abkhazian Official interview; Strokes 2018.

109 Engel 2018; O'Connor 2018a.

110 'South Ossetia National Team Refused to Participate in CONIFA Championship because of Georgia' 2015.

111 Gauthier 2019, 254-255.
} 
Sports diplomacy must be used in concert with other diplomatic tools. Thus, similar to sovereign states, contested territories should engage in sports diplomacy in parallel with other types of diplomacy, and it cannot be the only (or even the main) avenue used to further an entity's political, cultural or economic goals in relation to international actors. Furthermore, regardless of who undertakes sports diplomacy, it is vital to acknowledge that it has limitations, especially in times of conflict and realpolitik. ${ }^{12}$ That said, sports diplomacy is sometimes the only available diplomatic avenue, and its potential long-term impacts should not be disregarded. ${ }^{113}$

While CONIFA can help build a sense of common identity within the group that the CONIFA member represents, connect CONIFA members with each other and garner (positive) international media attention, its use as a tool for para- or protodiplomacy is limited. The representatives of contested territories still are not able to engage in diplomatic relations or talks with the most important players - recognised sovereign states. The existence of CONIFA highlights the lack of alternate avenues for contested territories to engage with sports teams from states or territories that are members of FIFA.

Another dimension is a critique of using sport for political gains. For sports fans and IFs, sport is supposed to be 'spiritual, magical, and sacrosanct' and, while sport can rise above politics, governments tend to hijack sports events and use them as a tool to promote political goals. ${ }^{114}$ The same is true for the governments of several contested territories who are conifa members. For example, in CONIFA this critique was echoed by a player from Tibet: 'We came here to play. Playing football and winning the tournament are the only objectives we have.'115 Similarly, by demanding to play as a separate entity, contested territories could contribute to the divide between their community and that of the base state. ${ }^{116}$ CONIFA officials understand that CONIFA is unlikely to lead to the political recognition of any of the entities its members represent but argue that it provides a platform for debating the issues these entities deal with and that the tournament is raising awareness. ${ }^{117}$

\footnotetext{
112 Gaillard 2013; Manzenreiter 2008, 422-423.

113 For example, sport diplomacy was the only diplomatic avenue between the United States and Iran, and between China and the United States via ping-pong diplomacy. See Chehabi 2001; Griffin 2014.

114 Murray 2012, 584-585.

115 Tenzin Nyendak, as cited in Withnall 2018, para. 23.

116 Gaillard 2013, 338, highlights that despite football being marketed as a tool to break down ethnic barriers in the Balkans and the Caucasus, this is not the case.

117 CONIFA Official-Global Team interview; conifa Official-Global Team/Abkhazian Official interview.
} 
This article has discussed why contested territories engage in para- and protosports diplomacy through participation in CONIFA. First, by participating in sports events under their own flag, contested territories are making a political statement to external audiences by showing their desire to change the status quo of the territories they represent, and to be recognised as relevant and legitimate actors on the international stage. Second, by participating in international platforms like CONIFA, members envisage changing their global image by presenting themselves in a positive light and showing a free-from-conflict image. Finally, these entities use sport to strengthen their own identity, build networks with other members and simply provide a platform for local players to play football.

Having presented the advantages and difficulties, it can be concluded that contested territories have issues in sports diplomacy that are similar to those in other types of para- and protodiplomacy: they have limited access to the fora in which to meet representatives of recognised states. Like other fora, access to international sports events is restricted, and the international tournaments they can participate in (e.g., CONIFA) do not provide an opportunity for them to engage with recognised states. The benefits of para- or protodiplomatic engagement with other contested territories is limited. Also, it cannot be definitively stated that it is easier for contested territories to engage in sports diplomacy compared to other types of diplomacy, especially as outcomes are hard to measure. Despite the goal of contested territories to be recognised as legitimate actors in international sport, most entities have failed to achieve this.

It must be noted that this study has been exploratory in nature. While this study did not find evidence that participation in CONIFA has so far had the diplomatic impact that the entities had hoped for, it must be noted that it is a slow process, and more time is needed to assess the long-term impact of paraand proto-sports diplomacy. When assessing how far participating in CONIFA can contribute to contested territories reaching their respective foreign policy goals, this study found little evidence that participation has had a discernible positive impact. Neither did participation contribute to the recognition of the entities' sporting sovereignty beyond CONIFA. On the contrary, participating could lead to even further sanctions from the base state. In relation to nation branding, the outcome seems more mixed; while the garnered international media attention may not be widespread, at the least some awareness of the existence of these entities is created. Moreover, all members are represented in a positive light. Third, while positive networks may have been built between 
the participating teams, beyond this the participants failed to build relations with the most important players in the international system - the representatives of recognised sovereign states. Finally, though beyond the scope of this study, the 'nation-building' aspect of sport seems to be an important outcome of participating in these sporting events.

\section{Bibliography}

Allison, Lincoln and Terry Monnington. 'Sports, Prestige and International Relations'. Government and Opposition 37 (1) (2002), 106-134.

Black, David and Black Peacock. 'Sports and Diplomacy'. In The Oxford Handbook of Modern Diplomacy, eds. Andrew F. Cooper, Jorge Heine, and Ramesh Thakur (Oxford: Oxford University Press, 2013), 708-725.

Bertoli, Andrew Douglas. 'Nationalism and Conflict: Lessons from International Sports'. International Studies Quarterly 61 (4) (2017), 835-849.

Brannagan, Paul Michael and Richard Giulianotti. 'The Soft Power-Soft Disempowerment Nexus: The Case of Qatar'. International Affairs 94 (5) (2018), 1139-1157.

Channel24. 'Ukrainian Footballers Permanently Disqualified'. Channel24, 17 October 2018. https://24tv.ua/ukrayinskih_futbolistiv_pozhittyevo_diskvalifikuvali nno48968.

Chehabi, Houchang E. 'Sport Diplomacy between the United States and Iran'. Diplomacy and Statecraft 12 (1) (2001), 89-106.

Conifa (Confederation of Independent Football Associations). 'Regulations Governing the Admission of New Members'. 2014. http://www.conifa.org/en/wp -content/uploads/2018/og/CONIFA-Internal-Regulation-Membership-Admission .pdf.

Conifa. 'Ahead of Tomorrow's @paddypower \#WFC2018 Final, Northern Cyprus Player @necatigench Explains What It Means to Play for His Country at Enfield'. Twitter, 8 June 2018a. https://twitter.com/ConIfaOfficial/status/100510267405 9104256 .

CONIFA. 'CONIFA Condemns Ukraine's Actions against Karpatalya'. 21 October 2018b. http://www.conifa.org/en/2018/10/21/conifa-condemns-ukraines-actions-against -karpatalya/.CONIFA. 'About Us'. n.d. https://www.conifa.org/en/about-us/.

Cook, Benjamin. 'We Went to This Year's Other World Cup Final: Stories from the Sidelines'. Huck, 15 June 2018. https://www.huckmag.com/outdoor/sport-outdoor /conifa-world-cup-final-2018/.

Cornago, Noé. 'Paradiplomacy and Protodiplomacy'. In Encyclopaedia of Diplomacy, ed. Gordon Martel (Oxford: Blackwell-Wiley, 2018), 1-15.

Criekemans, David. Regional Sub-State Diplomacy Today (Leiden: Brill Nijhoff, 2010). 
Deeley, Chris. Forgotten Nations (Hove: Pitch, 2019).

Der Derian, James. On Diplomacy: A Genealogy of Western Estrangement (Oxford: Basil Blackwell, 1997).

Ducharek, Ivo, Daniel Latouche and Garth Stevenson, eds. Perforated Sovereignties and International Relations: Trans-Sovereign Contacts of Subnational Governments (Westport, ст: Greenwood Press, 1988).

Engel, Matthew. 'World Football Cup an Alternative to FIFA and a Lesson in Geopolitics'. The Guardian, 1 June 2018. https://www.theguardian.com/football/2018/jun/o1/ world-football-cup-alternative-fifa-lesson-geopolitics.

Fan, Ying. 'Branding the Nation: Towards a Better Understanding'. Place Branding and Public Diplomacy 6 (2010), 97-103.

Field, Russell. 'For Kick and Country: The 2010 viva World Cup and Sport as a Site for Expressions of Alternate "National” Identities'. National Identities 16 (4) (2014), 377-393. FIFA (Fédération Internationale de Football Association). 'FIFA Statutes'. August 2018. https://resources.fifa.com/image/upload/the-fifa-statutes-2018.pdf?cloudid=whhn cbdzioozcuhmwfxa.

Gaillard, William. 'Football, Politics and Europe'. The Hague Journal of Diplomacy 8 (3-4) (2013), 333-340.

Gauthier, Ryan. 'Constructing Statehood through Sport: Football, Kosovo, and the Court of Arbitration for Sport'. Canadian Yearbook of International Law $5^{6}$ (2019), 220-257.

Ginnell, Luke. 'Conifa May Be Apolitical, but it Gives a Voice to Causes Straining to Be Heard'. Padypowers News, 10 May 2018. https://news.paddypower.com/conifa /2018/o5/10/conifa-paul-watson/.

Griffin, Nicholas. Ping-Pong Diplomacy: The Secret History behind the Game that Changed the World, 2nd ed. (New York: Scribner, 2014).

Grix, Jonathan and Michael Brannagan. 'Of Mechanisms and Myths: Conceptualising States' "Soft Power" Strategies through Sports Mega-Events'. Diplomacy and Statecraft 27 (2) (2016), 251-272.

Harris, Matt. 'Perble — But Seriously! The Far-Reaching Benefits of Paddy Power and CONIFA'. iConseils, 16 May 2018. https://www.sbcnews.co.uk/europe/2018/05/16/ matt-harris-perble-seriously-far-reaching-benefits-paddy-power-conifa/.

IOC (International Olympic Committee). 'Olympic Charter'. 1995. https://stillmed .olympic.org/Documents/Olympic\%2oCharter/Olympic_Charter_through _time/1995-Olympic_Charter.pdf.

IOC. 'Olympic Charter'. 2019. https://www.olympic.org/documents/olympic-charter.

Keating, Michael. 'Regions and International Affairs: Motives, Opportunities and Strategies', Regional and Federal Studies 9 (1) (1999), 1-16.

Kingston, Paul and Ian Spears, eds. States-within-States: Incipient Political Entities in the Post-Cold War Era (New York: Palgrave Macmillan, 2004). 
Kobierecki, Michał Marcin and Piotr Strożek. 'Sport as a Factor of Nation Branding: A Quantitative Approach'. International Journal of the History of Sport 34 (7-8) (2017), 697-712.

Manzenreiter, Wolfram. 'Football Diplomacy Post Colonialism and Japan's Quest for Normal State Status'. Sport in Society 11 (4) (2008), 414-428.

McHugh, James. 'Paradiplomacy, Protodiplomacy and the Foreign Policy Aspirations of Quebec and Other Canadian Provinces'. Canadian Foreign Policy Journal 21 (3) (2015), 238-256.

Mohammed, Herish Khali and Francis Owtram. 'Paradiplomacy of Regional Governments in International Relations: The Foreign Relations of the Kurdistan Regional Government (2003-2010)'. Iran and the Caucasus 18 (2014), 65-84.

Murray, Stuart. 'The Two Halves of Sports-Diplomacy', Diplomacy and Statecraft 23 (2012), 576-592.

O'Connor, Robert. 'Not FIFA: Karpatalja Wins Alternative Football World Cup'. Al Jazeera, 10 June 2018a. https://www.aljazeera.com/news/2018/o6/fifa-karpatalja -wins-alternative-football-world-cup-18o6og215407026.html.

O'Connor, Robert. 'Kabylia, Algeria and Taking Huge Risks to Play Football for Your Homeland'. Bleacher Report, 5 September 2018b. https://bleacherreport.com/ articles/2794125.

Orwell, George. 'The Sporting Spirit'. Tribune (London), 14 December 1945. http://www .orwell.ru/library/articles/spirit/english/e_spirit.

Padhi, Bishnupriya. 'Sports Diplomacy: South Africa and FIFA 2010'. Insight on Africa 3 (1) (2011), 55-70.

Pulleiro Méndez, Carlos. 'National Recognition and Power Relations between States and Sub-State Governments in International Sport'. International Journal of Sport Policy and Politics (2020), 1-17.

Rofe, J. Simon. 'Sport and Diplomacy: A Global Diplomacy Framework'. Diplomacy and Statecraft 27 (2) (2016), 212-230.

Rookwood, Joel. 'The Politics of ConIFA: Organising and Managing International Football Events for Unrecognised Countries'. Managing Sport and Leisure (2019), 1-15.

Shobe, Hunter and Geoff Gibson. 'Cascadia Rising Soccer Region and Identity'. Soccer and Society 18 (7) (2017), 953-971.

'South Ossetia National Team Refused to Participate in Conifa Championship because of Georgia'. Regnum, 17 June 2015. https://regnum.ru/news/sport/1934215 .html.

Strokes, Brian. 'There Are Two Protesters outside the Ground and a ConIFA Official Has a Word with Them. He Repeatedly States that the "Tournament is Not about Politics”. \#WFC2O18 \#CONIFA @TheBootifulGame'. Twitter, 31 May 2018. https:// twitter.com/brianstokes92/status/1002141187501944832. 
Štulajer, Ivan and Matúš Štulajter. 'Sport in the Context of International Relations'. Journal of Modern Science 29 (2) (2016), 381-388.

UNPO (Unrepresented Nations \& Peoples Organization). 'Football for Peace Tournament — UNPO World Cup 2017'. 17 June 2017. https://unpo.org/article/2011o. Utomo, Ario Bimo. 'The Paradiplomatic Role of the ConIFA in Promoting SelfDetermination of Marginalised Entities'. Global and Strategis 13 (1) (2019), 25-36.

Weeks, Jonny. 'The Alternative World Cup'. The Guardian, 9 June 2018. https://www .theguardian.com/football/ng-interactive/2018/jun/og/the-alternative-world-cup.

Williams, Matthias and Pavel Polityuk. 'Ukraine Accuses Soccer Team of "Supporting Separatism". Reuters, 11 June 2018. https://www.reuters.com/article/us-ukraine -soccer-investigation/ukraine-accuses-soccer-team-of-supporting-separatism -idUSKBN1J72BH.

Withnall, Adam. 'Tibet's Participation in Alternative 'World Cup' Ruffles Chinese Feathers'. The Independent, 2 June 2018. https://www.independent.co.uk/news /world/asia/conifa-world-football-cup-tibet-china-a8380436.html.

\section{Ramesh Ganohariti}

is a PhD student at the School of Law and Government at Dublin City University, Ireland. His research focuses on the intersection between citizenship and contested statehood in post-Soviet de facto states. Ramesh holds an Msc in International Relations and Diplomacy (Leiden University), prior to which he graduated with a Bachelor of Social Science majoring in Culture Studies and Languages (Ritsumeikan Asia Pacific University). Before starting his $\mathrm{PhD}$, he worked as a tutor for the Bachelor of Security Studies program at Leiden University.

\section{Ernst Dijxhoorn}

is Assistant Professor at the Institute of Security and Global Affairs. He obtained his PhD in War Studies from King's College London in 2014, and holds a MA in International Peace and Security (King's College London) and an LLM in International Public Law (University of Amsterdam). Prior to joining the Institute of Security and Global Affairs, he taught at the Department of War Studies at King's College London. 